\title{
Moderated Mediation Effects of Economic Freedom on FDI Under Different Levels of Political Stability
}

\author{
Ilija Stojanović ${ }^{1}$ \\ ${ }^{1}$ Al Ghurair University, Dubai, United Arab Emirates \\ Correspondence: Ilija Stojanović, Al Ghurair University, Dubai, United Arab Emirates. E-mail: \\ ilija.stojanovic1976@gmail.com
}

Received: Ocotber 2, 2020

Accepted: November 17, 2020

Online Published: December 20, 2020

doi:10.5430/rwe.v11n6p269

URL: https://doi.org/10.5430/rwe.v11n6p269

\begin{abstract}
Global competitiveness position is perceived as a highly relevant enabler for attracting foreign direct investments. Our study goes beyond this well-known fact to understand whether economic freedom indicators are relevant cause for global competitiveness in attracting foreign direct investments and how this relationship behaves in different conditions of political stability. We focused our empirical study to mediating and moderating processes through which global competitiveness is linked with FDI. We developed and tested a second stage moderated parallel mediation model to observe mediating effects of economic freedom and moderating effects of political stability. Our research was focused on mediating effects of several indicators of Economic Freedom including Size of Government, Legal System \& Property Rights, Sound Money, Freedom to trade internationally and Regulation. The findings indicate that Legal System \& Property Rights and Freedom to trade internationally have positive conditional indirect effects within the model. Freedom to trade internationally is a much more sensible mediator variable in case of different levels of political stability while Legal System \& Property Rights is not significantly affected by political stability, strengthening economic freedom in these two dimensions provides an enhanced effect of existing competitiveness on FDI growth. We recognized that political stability has no influence on the indirect effects between competitiveness and inward FDI produced by Legal System \& Property Rights, as one of the dimensions of economic freedom. Therefore, to attract FDI in unstable political conditions is very useful to establish a proper legal system and adequate protection of property rights. In such a legal environment, foreign investors will feel comfortable regardless of the political risks in the country. Freedom to trade internationally is a much more sensible mediator variable under the influence of political instability.
\end{abstract}

Keywords: global competitiveness, economic freedom, foreign direct investment, political stability

JEL classification: F21

\section{Introduction}

Foreign direct investments play a very important role in economic life. Almfraji \& Almsafir (2014) pointed on the literature that discusses the effects of foreign direct investments (FDIs) on economic growth. Having in mind the importance of FDIs on economic growth, some scholars promote the various factors in attracting FDIs (Popovici \& Călin, 2015; Zlatković, 2016). Several studies have shown that global competitiveness is a highly important factor in attracting foreign direct investment inflow. Following this line of thinking, Popovici \& Călin $(2015$, p.55) argued that "competitiveness is a determinant factor for foreign investors".

Different studies confirmed the existence of positive effects of competitiveness on foreign direct investment. However, it is not evident what are the causes for global competitiveness to affect the inflow of foreign direct investment. These studies did not consider the various factors that may act through mediation processes on direction and intensity of the effects of global competitiveness on the level of FDIs. The reason for conducting this study is to identify moderation and mediation factors that increase or eventually decrease the effects of country competitiveness on the level of foreign direct investments. The existing literature lacks an analysis of these additional factors which, despite the existence of certain competitive advantages, differently affects the inflow of foreign direct investment in different countries. Thus, we put our research focus to analyse how economic freedom mediates the effects of country competitiveness on foreign direct investments. Given the different situation in terms of political stability that may affect the inflow of foreign direct investments, our additional area of academic interest is to determine how different political conditions 
affect this relationship between competitiveness and foreign direct investments.

Very little attention is paid in the current literature to explain how economic freedom under different conditions of political stability affects the relationship between global competitiveness and foreign direct investment. It is not sufficiently observed how economic freedom and internal political stability affect the relationship between competitiveness and foreign direct investment. Thus, we are keen to understand whether economic freedom indicators are relevant causes for global competitiveness in attracting foreign direct investments and how this relationship behaves in different conditions of political stability. Following this problem, we set up our research question as follows: Do different dimensions of economic freedom under different conditions of political stability contribute to increasing or decreasing the effects of global competitiveness on foreign direct investments?

This study began with the assumption that different indicators of economic freedoms have different mediation effects on the relationship of competitiveness to foreign investment. Furthermore, it assumed that different levels of political stability will significantly have effect in the research model. The aim of this study is to fill the gap in the existing literature by including additional mediation and moderation effects to explain how competitiveness may influence foreign direct investment inflow under different levels of economic freedom and political stability.

\section{Literature Review}

Foreign direct investments are highly important for developing countries especially because they provide different benefits such as provision of capital or transfer of technology. Positive effects of global competitiveness on foreign direct investments is well-known fact from practice and confirmed by different empirical studies (Popovici \& Călin, 2015; Anastassopoulos, 2007; Zlatković, 2016; Curtis, Rhoades, \& Griffin, 2013).

Anastassopoulos (2007), based on the sample of $15 \mathrm{EU}$ member countries, found a positive effect between competitiveness and FDI inflows. However, the study showed some differences in FDI determinants between the north and south part of Europe. Other studies showed that competitiveness is also very important factor for FDI in Central and Eastern European countries (Paul, Popovici, \& Călin, 2014; Popovici \& Călin, 2012). Zlatković (2016) found very similar results with positive effects of each competitiveness pillar and FDI for the Balkan countries. Very extensive research in this field has been conducted by Curtis, Rhoades, \& Griffin (2013). Their very extensive study confirmed that global competitiveness is an important factor in attracting inward FDI.

In the literature we can also find some studies that analyse the effects of other factors on foreign direct investments, such as economic freedom and political stability. We will continue to elaborate the existing literature about the effects of these factors on FDIs inflows.

\section{Effects of economic freedom}

Quazi (2007) pointed on the literature about different variables that influence FDI such as market size or trade openness. Some studies indicate economic freedom as one of the major determinants for inflow of FDIs. According to Caetano \& Caleiro (2009, p.65), "economic freedom means the degree to which a market economy is in place, where the central components are voluntary exchange, free competition, and protection of persons and property." In order to monitor economic freedom, different indicators are established for its measurement. Pearson, Nyonna, \& Kim (2012) highlight especially two indexes: Fraser's Institute Economic Freedom World (EFW) and Heritage Foundation Economic Freedom Index of the World. Our study utilizes the EFW index.

There are several studies discussing the relationship between economic freedom, economic performance, and foreign direct investment. A good overview of such studies is given by Sovbetov \& Moussa (2017). Most of these studies are focused on specific regions. One of significant research was exercised by Pearson et al. (2012) who analysed the effects of economic freedom and other economic factors on FDI at the level of federal states in the USA. They found a significant positive effect of economic freedom on FDI in all US federal states.

Fofana (2014) observed how different indicators of economic freedom influence foreign direct investment in 25 Western European and 26 Sub-Saharan countries in the period through 2001-2009. He analysed the impact of institutional variables of economic freedom. According to his empirical results, the aggregate economic freedom index has no significant effect on FDI for Africa, which is opposite to previously mentioned studies that indicates positive effects in other regions. Very similar findings were presented by Mohamed \& Sidiropoulos (2010) who investigated how economic freedom affects FDI in MENA countries by observing the period from 1975 to 2006. They found that trade freedom is an insignificant factor.

The previous literature review has revealed diversity of empirical results about the effects of economic freedom on FDI. Especially interesting empirical results are provided by Quazi (2007) who analysed seven East-Asian countries in the 
period from 1995 until 2000. From this study one can find an unexpected result by which economic freedom is an insignificant factor for FDI. However, this is in case when China was included in the sample. After excluding China from the sample, then economic freedom becomes a statistically significant factor for FDI.

\section{Effects of political stability}

Many scholars investigated how political stability affects foreign direct investments. The reason for these efforts can be found in the fact that the risk perceived by investors is crucial for investment decisions, particularly for investments to be made outside of the country of origin (Caetano \& Caleiro, 2009). Barro (1991) and Corbo \& Schmidt-Hebbel (1991) argued that political instability reduces economic growth and investments by creating an uncertain economic environment. Rani \& Batool (2016) argued that due to political instability leading to decreasing investment level. One of such examples is Sub-Saharan Africa in which high political risk does not contribute to investing interest (Asiedu, 2002).

Nazeer \& Masih (2017) indicate that "political instability is considered by economists as a serious disease harmful to economic performance". Moreover, "political instability has been a harmful factor that would hinder the flow of FDI and the growth of an economy" (Nazeer \& Masih, 2017, p.2). Krugman (2009) highlighted that investor's confidence is a very important economic element. According to Brada et al. $(2006$, p.6) "investment, including FDI, is a forward-looking activity based on investors' expectations regarding future returns and the confidence that they can place on these returns. Thus, a decision about FDI requires some assessment of the political future of the host country." Busse \& Hefeker (2007) analysed what is most important for multinational corporations when making their own investment decisions. According to them, the level of FDI is conditioned especially with government stability, absence of internal conflict and ethnic tensions, basic democratic rights and ensured law and order. Busse \& Hefeker (2007) also found that FDI is under influence of the investment profile, internal and external conflicts, ethnic tensions, and democratic accountability.

Despite the established notion among investors, one can find different opinions among scholars about the effects of political instability on FDI. Kim (2010) argues FDIs inflows are higher for politically unstable countries expressing an opposed view with many other scholars. Schneider \& Frey (1985) came to similar empirical results confirming the inverse relation between political instability and FDI. Contrary to previously mentioned findings, Jaspersen et al. (2000) and Fernández-Arias \& Hausmann (2001) found no significant relations between political stability and foreign direct investment. Loree \& Guisinger (1995) provided their empirical findings according to which political stability had a statistically significant negative impact in 1982, but without statistically significant effect in 1977. Carmignani (2003) also provided an excellent review of the literature discussing the relations between political instability and economic performance.

Brada, Kutan, \& Yigit (2006) focused their attention on the countries in transition including transitional economies from Central Europe, the Baltics, and the Balkans. They found that conflict and political instability has a smaller impact on FDI flows for transition countries compared to West European countries and that stabilization reforms have contributed to FDI inflows. These authors found that conflict and instability, together with the challenges of stabilization reforms occurred in Balkan countries reduced FDI inflows below what one would expect for comparable West European countries. Based upon empirical study, Kurecic \& Kokotovic (2017) conclude that there is a long-term relationship between political stability and FDI for the panel of small economies, while empiric evidence of such a relationship is lacking for both panels of larger and more developed economies.

\section{Putting all together}

From the previous literature review, we found how scholars perceive the individual effects of competitiveness, economic freedom, and political stability on FDIs. However, all these factors are present at the same time. Thus, we should understand the interlinkages between all these factors on the inflow of FDIs. Thus, the aim of this study is to overcome shortcomings of previous studies putting all these factors into one research model.

There are few studies clarifying relations of economic freedom and political instability on economic performance and FDI. Bayar \& Aytemiz (2015) indicated that both economic freedom and political stability has a positive long-term impact on economic growth. Evidence from Bangladesh indicates that the FDI inflow is significantly decreased because of the absence of economic freedom and increased political risk (Quazi \& Quddus, 2018). Sovbetov \& Moussa (2017) understood the importance to observe the macroeconomic impact of economic freedom on foreign direct investments inflows in often neglected nations such as Fragile and Conflict-Affected states, Sub-Saharan, Oceania, and Post-Soviet countries. Their study finds a positive impact of economic freedom on FDI in global cases. The highest impact is recorded in European countries, whereas the lowest ones are documented in Fragile-Conflict affected states, 
Sub-Saharan zone, and Oceania. They gave an interesting observation about Arab countries where FDI has been negatively affected by conflicts.

Looking at the previous literature on the effects of specific indicators of economic freedom on foreign direct investment, it is evident that this factor is not considered a mediator factor in the research model. The reasons why we should analyse the mediating effects of economic freedom could be found in the case of China that opposes traditional notions about the effects of economic freedom. Having in mind that China is very attractive for FDI, at the same time receives solid ranks from the Global Competitiveness Report and low ranks by the Economic Freedom of the World (Allen, Qian, \& Qian, 2005), we found justified to observe how individual indicators of economic freedom mediate the relationship of global competitiveness and the level of inward FDI. In this way we can find out whether the individual indicators of economic freedom are causes of a positive relationship between competitiveness and foreign direct investment. Thus, we set up our first hypothesis to confirm or oppose the claim that the positive relationship between global competitiveness and foreign direct investment will be mediated by selected indicators of economic freedom. We set up Hypothesis 1: Global competitiveness will attract more foreign direct investment in countries with a higher level of economic freedom.

Now, we should also take into consideration the level of political stability and its effect on FDIs. According to Singh \& Jun (1995), econometric tests to identify relationships between foreign direct investment and political risk often fail. They express the opinion that political instability, as a qualitative phenomenon, is a complex issue. Therefore, we will consider if there are any moderation effects of political stability on the relationship between selected indicators of economic freedom on foreign direct investment. Following this empirical gap, we set up our Hypothesis 2: The influence of economic freedom on foreign direct investment will be stronger in countries that are more politically stable.

From the literature we found not enough evidence on the conditional indirect effect of competitiveness on FDI considering mediation effects of economic freedom and moderating effects of political stability. Ferreira et al. (2016) observed the moderating effect of corruption on the ability to attract FDI. This study is focused on a narrower issue and not covering our research question. We shall look back at the study provided by Nageswaran (2004) who observed the political regime in China. Although run by a one-party system, China shows significant locational advantages, with capacity for making quick and smooth decisions. This scholar points that open democracy involves reconciling the interests of multiple stakeholders that could be against the interest of foreign investors. Thus, he believes that the absence of democratic institutions in China with high control of government have created a political environment simulative for FDI.

We also witness significant changes in the views of the USA and China in terms of economic freedom, especially regarding free trade. This opens an exciting area for empirical analysis. In our study we are interested to understand whether there are significant indirect effects of global competitiveness on foreign direct investment, mediated through selected indicators of economic freedom and moderated by political stability. Having this in mind, we set up our Hypothesis 3: Economic freedom will have a stronger conditional indirect effect of global competitiveness on foreign direct investment for politically more stable countries.

Why is this study important? Because it studies the complexity of relationships of different factors in attracting foreign direct investments. Previous studies focused on the effects of individual factors on FDIs. With this study one can get more detailed insight into moderated-mediation relations of economic freedom and political stability on the effects of competitiveness on FDIs inflow.

\section{Methodology}

This study contributes to our understanding of mediating and moderating processes through which individual country competitiveness within the global environment is linked with the level of foreign direct investment. We developed a moderated mediation model linking global competitiveness to foreign direct investment. Our research model posits that the effect of global competitiveness on foreign direct investment is mediated by the level of economic freedom represented through parallel mediation variables including Size of Government, Legal System \& Property Rights, Sound Money, Freedom to trade internationally and Regulation, as specified by the Economic Freedom of the World index. The study also includes the relationship between indicators of economic freedom and foreign direct investment moderated by the level of political stability. The research model enables deeper understanding whether economic freedom and its indicators are important for attracting foreign direct investment under different levels of political stability. The conceptual model is shown in the following figure. 


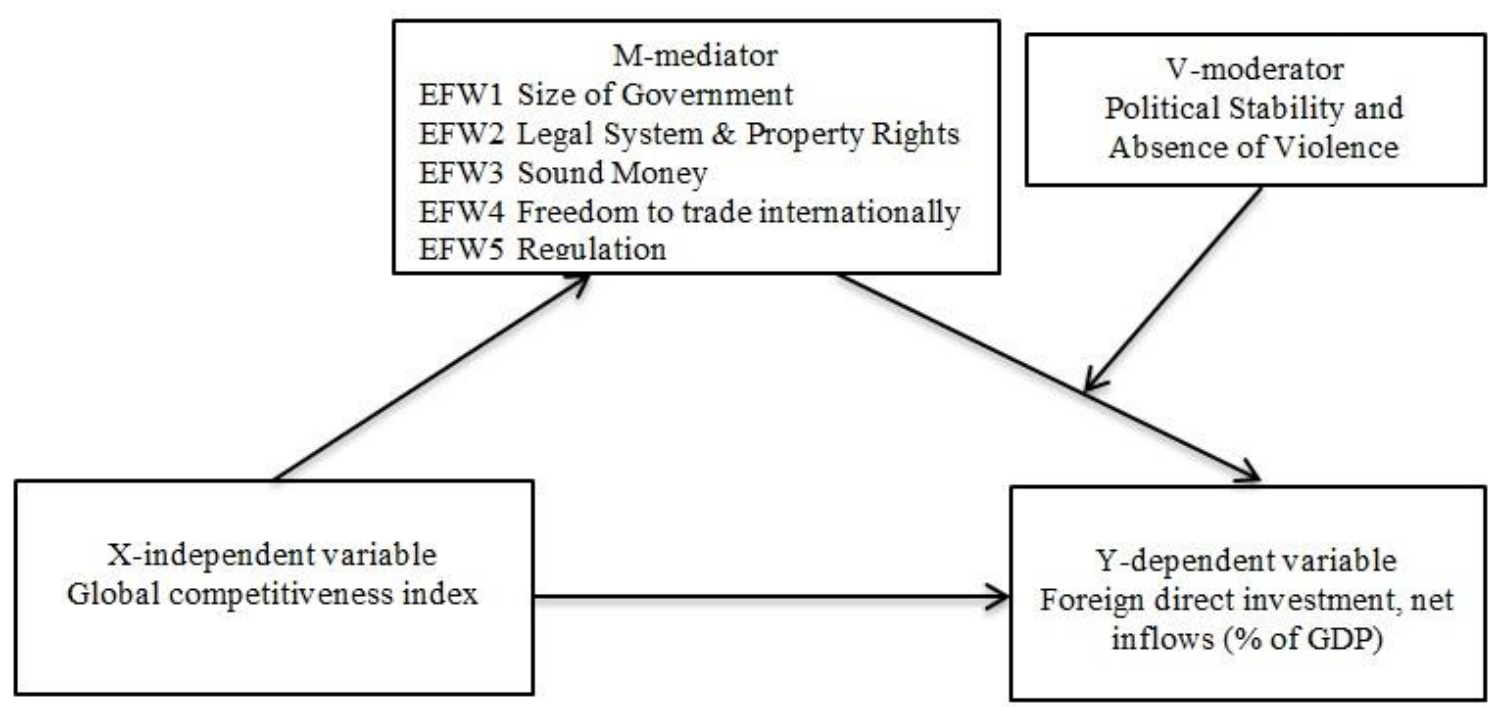

Figure 1. Research conceptual model

From the empirical point of view, we implemented a second stage moderated parallel mediation model (Edwards \& Lambert, 2007), also known as model 14 introduced by Hayes (2013). We were especially interested to understand conditional indirect effects of our independent variable on dependent variables under moderated mediation. To get full overview of the findings within proposed model, we conducted our research in three stages (Preacher, Rucker, \& Hayes, 2007):

Step 1- Mediation analysis:

This step enables an answer on the question about whether indicators of economic freedom represent relevant causes for competitiveness in attracting foreign direct investment. With parallel mediation analysis we were able to understand whether individual indicators of economic freedom provide statistically significant indirect effect of competitiveness on the level of foreign direct investment. Mediation tests a relationship where the effect of global competitiveness, as independent variable (X), on foreign direct investment, as dependent variable (Y), is explained by economic freedom, as mediator variable (M). These are the basic assumptions to confirm the existence of mediation effect (Baron \& Kenny, 1986; Preacher \& Hayes, 2008):

significant association between IV and DV (path c)

significant association between IV and mediator (path a)

significant association between mediator and DV (path b)

statistically non-significant (full-mediation) or reduced statistically significant (partial mediation) association between IV and DV after controlling for mediator (path c').

Step 2 - Moderation analysis:

This step enables understanding how different indicators of economic freedom affect foreign direct investment and how this relationship behaves in different conditions of political stability. We analysed moderation effects of political stability only for those individual indicators of economic freedom that were confirmed in the previous step as statistically significant mediators. For empirical purposes only, we observed selected indicators of economic freedom as our independent variable (X), foreign direct investment as our dependent variable (Y) and political stability as our moderator (M). In this step we searched for influence of $\mathrm{M}$ on the relationship between $\mathrm{X}$ to $\mathrm{Y}$ not only for the overall model, but also for different values of political stability: average (sample mean), low (-1 standard deviation) and high (+1 standard deviation).

Step 3 - Moderated mediation analysis:

This step enables understanding how mediated relationships of selected indicators of economic freedom between global competitiveness and foreign direct investment will be moderated by the level of political stability. The proposed model integrates moderated regression analysis and path analysis; expresses direct, indirect, and total effects of mediation; and shows how paths vary when the moderator variable is included (Edwards \& Lambert, 2007). This 
model analyses the influence of a fourth (moderator) variable on the mediated relationship between $\mathrm{X}$ and $\mathrm{Y}$ (Preacher et al., 2007) for those indicators of economic freedom that have been confirmed as statistically significant mediators in previous steps. Thus, we observed how mediating effect behaves when is thought to be moderated by some variable (Baron \& Kenny, 1986). We put focus on moderation effects on path $\mathrm{b}$ of parallel mediation model. The findings from this step enabled our understanding about conditional indirect effects known as moderated mediation effects. In assessing indirect effects, we used bootstrapping method which has been suggested in order to generate confidence intervals (Bollen \& Stine, 1990; Lockwood \& Mackinnon, 1981; MacKinnon, Lockwood, \& Williams, 2004; Preacher $\&$ Hayes, 2004; Shrout \& Bolger, 2002). Bootstrapping has been promoted as a very useful resampling strategy which does not require any assumptions about the shape of the sampling distribution (Edwards \& Lambert, 2007; Preacher et al., 2007). For that purpose, we used 5000 number of bootstrap samples for biased corrected bootstrap confidence intervals through the analysis of the effect of moderators in this model.

Finally, we analysed index of moderated mediation proposed by (Hayes, 2015) to integrate moderation and mediation analysis. During empirical research we used SPSS macro for a command PROCESS Version 2.13 (Hayes, 2013) as a stand-alone and comprehensive tool which integrates different functions including bootstrapping methods.

Our research sample was based on $N=215$ countries in the time interval from 2000 to 2016. The final number of observations for individual analyses depended on the availability of comparable data of variables in the model. Within the second stage moderated mediation model we observed sample size with $N_{t}=1291$ cases. From established model we identify several variables presented in the following table:

Table 1. Research variables

\begin{tabular}{|c|c|c|}
\hline Variable & Initials & Interpretation \\
\hline Global Competitiveness Index & GCI & $\begin{array}{l}\text { "competitiveness as the set of institutions, policies, and factors } \\
\text { that determine the level of productivity of a country" (Schwab et } \\
\text { al., 2017, p.317) }\end{array}$ \\
\hline $\begin{array}{l}\text { Foreign direct investment, net } \\
\text { inflows (\% of GDP) }\end{array}$ & FDIgdp & $\begin{array}{l}\text { "the net inflows of investment to acquire a lasting management } \\
\text { interest ( } 10 \text { percent or more of voting stock) in an enterprise } \\
\text { operating in an economy other than that of the investor" (World } \\
\text { Bank Open Data) }\end{array}$ \\
\hline EFW1 Size of Government & EFW1 & $\begin{array}{l}\text { "As spending and taxation by government, and the size of } \\
\text { government-controlled enterprises increase, government } \\
\text { decision-making is substituted for individual choice and } \\
\text { economic freedom is reduced." (Gwartney et al., 2017, p.3) }\end{array}$ \\
\hline $\begin{array}{l}\text { EFW2 Legal System \& Property } \\
\text { Rights }\end{array}$ & EFW2 & $\begin{array}{l}\text { "Protection of persons and their rightfully acquired property is a } \\
\text { central element of both economic freedom and civil society. } \\
\text { Indeed, it is the most important function of government." } \\
\text { (Gwartney et al., 2017, p.3) }\end{array}$ \\
\hline EFW3 Sound Money & EFW3 & $\begin{array}{l}\text { "Inflation erodes the value of rightfully earned wages and } \\
\text { savings. Sound money is thus essential to protect property } \\
\text { rights. When inflation is not only high but also volatile, it } \\
\text { becomes difficult for individuals to plan for the future and thus } \\
\text { to use economic freedom effectively." (Gwartney et al., 2017, } \\
\text { p.5) }\end{array}$ \\
\hline $\begin{array}{l}\text { EFW4 Freedom } \\
\text { internationally }\end{array}$ & EFW4 & $\begin{array}{l}\text { "Freedom to exchange-in its broadest sense, buying, selling, } \\
\text { making contracts, and so on-is essential to economic freedom, } \\
\text { which is reduced when freedom to exchange does not include } \\
\text { businesses and individuals in other nations." (Gwartney et al., } \\
2017, \text { p.5) }\end{array}$ \\
\hline EFW5 Regulation & EFW5 & $\begin{array}{l}\text { "Governments not only use a number of tools to limit the right } \\
\text { to exchange internationally, they may also develop onerous } \\
\text { regulations that limit the right to exchange, gain credit, hire or } \\
\text { work for whom you wish, or freely operate your business." } \\
\text { (Gwartney et al., 2017, p.5) }\end{array}$ \\
\hline
\end{tabular}


EFW6 Political Stability and Absence PS of Violence "perceptions of the likelihood that the government will be destabilized or overthrown by unconstitutional or violent means, including politically-motivated violence and terrorism" (Kaufmann et al., 2010, p.4)

\section{Results}

According to proposed methodology, we present the findings from three different steps.

Step 1 - Parallel mediation

According to parallel mediation analysis, we found statistically significant association between independent and dependent variables (path $c$ ). In this way, we have provided an empirical background for continuation of empirical research confirming the significant positive effect of global competitiveness on the level of foreign direct investment $b=2.11, t(1289)=2.42, p<.05, C I[-10.71,-4.21]$. This result supports previous theoretical thinking of the positive effect of global competitiveness status on foreign direct investment. Once we get this confirmation, further results will show how individual indicators of economic freedom contribute to such a relationship of independent and dependent variables. We found a statistically significant effect between independent variable and mediator for each individual indicator of economic freedom on the path $a$. However, on the path $b$ there is an absence of statistical significance for the following indicators: Size of Government, Sound Money and Regulation. We found statistical significant results only for indicators Legal System \& Property Rights with the result $b=4.05, t(1284)=5.24, p<.05, C I[2.53,5.56]$ and Freedom to trade internationally with the result $b=3.20, t(1284)=3.34, p<.05, C I[1.32,5.07]$. Direct effect from the path $c^{\prime}$ with the result $b=-7.46, t(1289)=4.50, p<.05, C I(-),[-10.71,-4.21]$. Since direct effect (path $c^{\prime}$ ) is still statistically significant with reduced effect compared to total effect (path $c$ ), we confirmed the existence of partial mediation. These results are shown in the figure below.

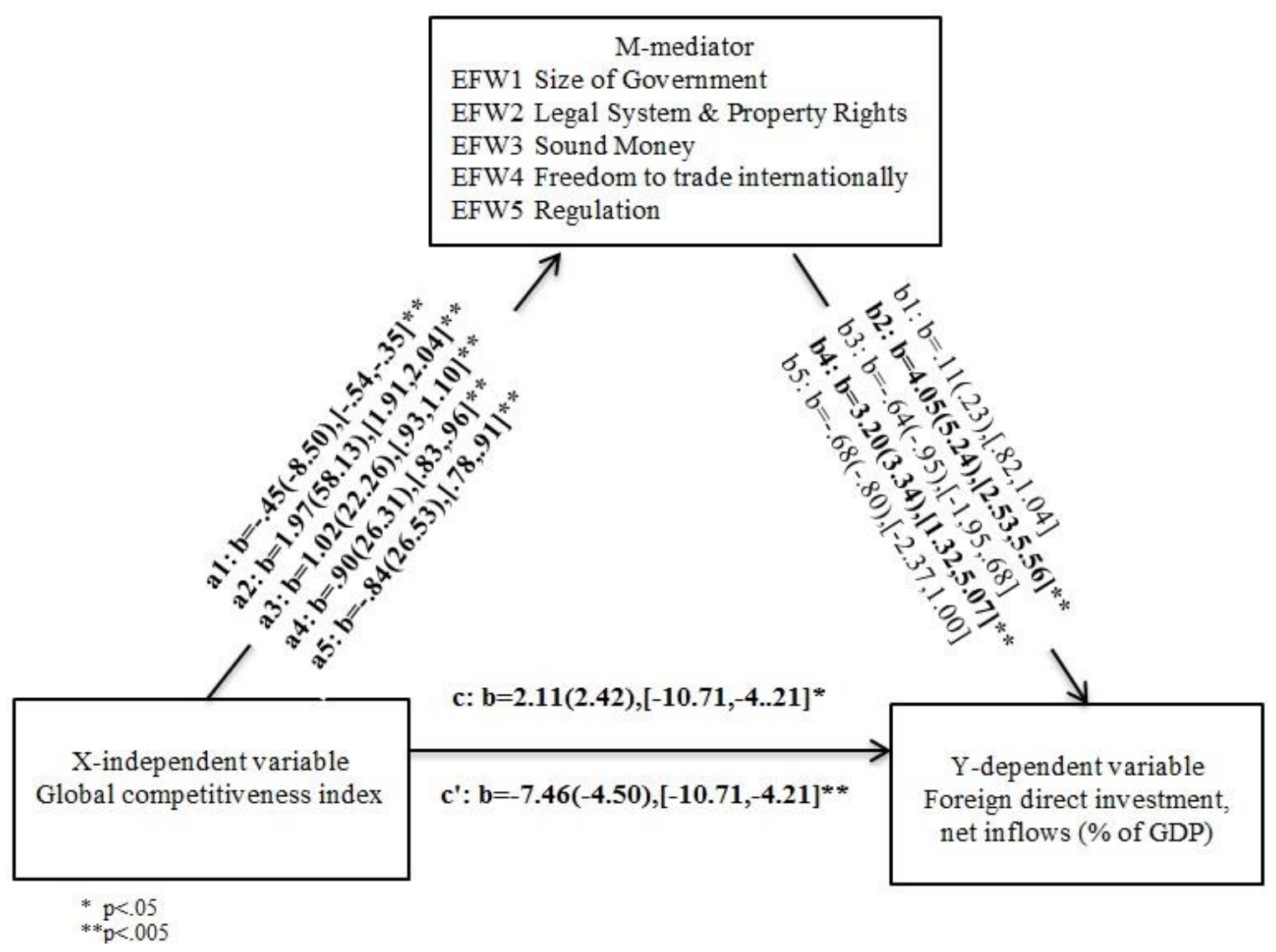

Figure 2. Mediation 
From the previous figure focusing on the results in path $b$, but also from the table that provides insight into the results of indirect effects of independent on dependent variable, it can be concluded that the existence of partial mediation only applies to mediators EFW2 and EFW4. According to the Sobel test, we found statistical significant results for variable EFW2 where $Z=5.22, p<.05, \kappa^{2}=7.98$ and EFW4 where $Z=3.31, p<.05, \kappa^{2}=2.86$. Thus, we will use only Legal System \& Property Rights and Freedom to trade internationally as significant mediators in further steps of empirical analysis.

Table 2. Indirect effect of $\mathrm{X}$ on $\mathrm{Y}$

\begin{tabular}{lrrrr}
\hline & Effect & Boot SE & BootLLCI & BootULCI \\
\hline TOTAL & 9,568 & 2,689 & 5,533 & 16,129 \\
\hline EFW1 &,- 048 &, 146 &,- 299 &, 289 \\
\hline EFW2 & 7,977 & 2,333 & 4,453 & 13,674 \\
\hline EFW3 &,- 648 &, 346 & $-1,330$ &, 051 \\
\hline EFW4 & 2,863 &, 741 & 1,708 & 4,747 \\
\hline EFW5 &,- 576 &, 472 & $-1,732$ &, 176 \\
\hline
\end{tabular}

Step 2 - moderation

In the further analysis we conducted two separate moderation analysis in which we used Legal System \& Property Rights and Freedom to trade internationally as our independent variables. For EFW2 as an independent variable, we found a statistically significant result of the moderation model with the result $F(3,2094)=15.44, \mathrm{p}<.05, R^{2}=.03$. Within the model we were particularly interested in the product of independent variable and moderator $X^{*} M$ which represents our interaction coefficient between Legal System \& Property Rights and Political stability and absence of violence. We found a statistically significant effect of the interaction coefficient $b=.76, t(2094)=2.83, p<.05, C I[.23,1.28]$. For EFW4 as an independent variable, we confirmed a statistically significant effect of the overall moderation model with the result $F(3,2094)=14.81, p<.05, R^{2}=.04$. After observing individual coefficients in the model, we found statistically significant interaction coefficient representing the product of Freedom to trade internationally and Political stability and absence of violence with the result $b=1.84, t(2094)=3.90, p<.05, C I[.914,2.77]$.

By further analysis of conditional effects of Legal System \& Property Rights on foreign direct investment under different levels of political stability, we found statistically significant effects for average and high levels of political stability. There is an absence of a statistically significant effect of Legal System \& Property Rights on foreign direct investment when the level of political stability is low. Very similar results we found by analysis of conditional effects of Freedom to trade internationally on foreign direct investment. Likewise, we found a statistically significant effect of Freedom to trade internationally on foreign direct investment only for average and high levels of political stability. However, the intensity of increasing the effect from an average to a high degree of political stability is higher when we look on conditional effects of Freedom to trade internationally on foreign direct investment from $b=1.62$ (average level of political stability) to $b=3.35$ (high level of political stability). For conditional effects of Legal System \& Property Rights on foreign direct investment we found transition from $b=.39$ (average level of political stability) to $\mathrm{b}=1.09$ (high level of political stability). 


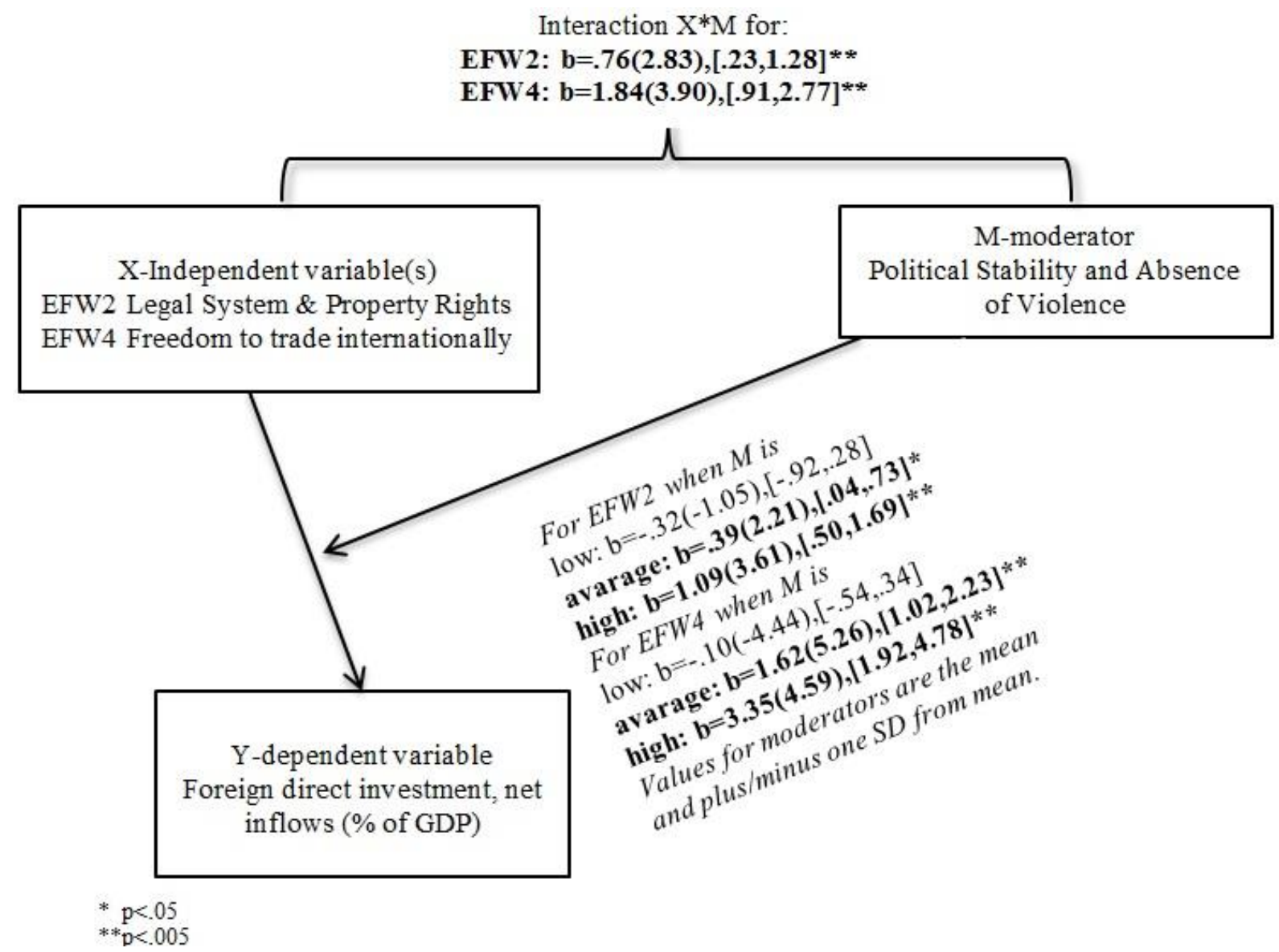

Figure 3. Moderation

Step 3 - Moderated mediation with model 14

Since we found in separate steps statistically significant mediation and moderation models for EFW2 and EFW4 variables, in this step we will put focus on moderated mediation effects. Primarily, we analysed statistical significance of the product between mediator and moderator $M^{*} V$ in dual stage moderated mediation model. Observing the effect of interaction between Legal System \& Property Rights and Political Stability and Absence of Violence, we did not find a statistically significant effect because of $b=.10, t(1284)=.28, p=.78, C I[-.62, .82]$. We found a statistically significant effect of interaction between Freedom to trade internationally and Political Stability and Absence of Violence with the result $b=3.08, t(1284)=.3 .21, p<.05, C I[1.20,4.95]$.

Within the dual stage moderated mediation model, we found a statistically significant conditional indirect effect of global competitiveness on foreign direct investment at different values of political stability (low, average and high) for both indicators of economic freedom: Legal System \& Property Rights and Freedom to trade internationally. These results are shown in figure 4 . These results confirm the existence of mediation effects of both selected variables of economic freedom.

The intensity of the change in value of the conditional indirect effect of independent variable on dependent variable under different levels of political stability is higher for EFW4 (low $b=.59$; average $b=3.05$; high $b=5.52$ ). For EFW2 we noticed less intensity of changes of this effect for different levels of political stability (low $b=4.77$; average $b=4.94$; high $\mathrm{b}=5.12$ ). Moreover, we did not find evidence of the existence of moderated mediation for Legal System \& Property Rights since Index of moderated mediation is not statistically significant. The result of Index of moderated mediation for this indicator is $b=.20, C I[-1.03,1.79]$. Having in mind that the bootstrap confidence interval crosses through the value of 0 , we reject the claim about existence of moderated mediation for Legal System \& Property Rights. For Freedom to trade internationally we found a statistically significant moderated mediation effect with Index of moderated mediation $b=2.76, C I[1.39,4.89]$. 
Based on these results we can confirm that Legal System \& Property Rights and Freedom to trade internationally, as indicators of economic freedom, represent relevant causes for competitiveness in attracting foreign direct investment. Freedom to trade internationally is a much more sensible mediator variable for changes in the level of political stability while Legal System \& Property Rights is not significantly affected by changes in the level of political stability. By improving political stability, Freedom to trade internationally improves the positive effect of competitiveness on FDI.

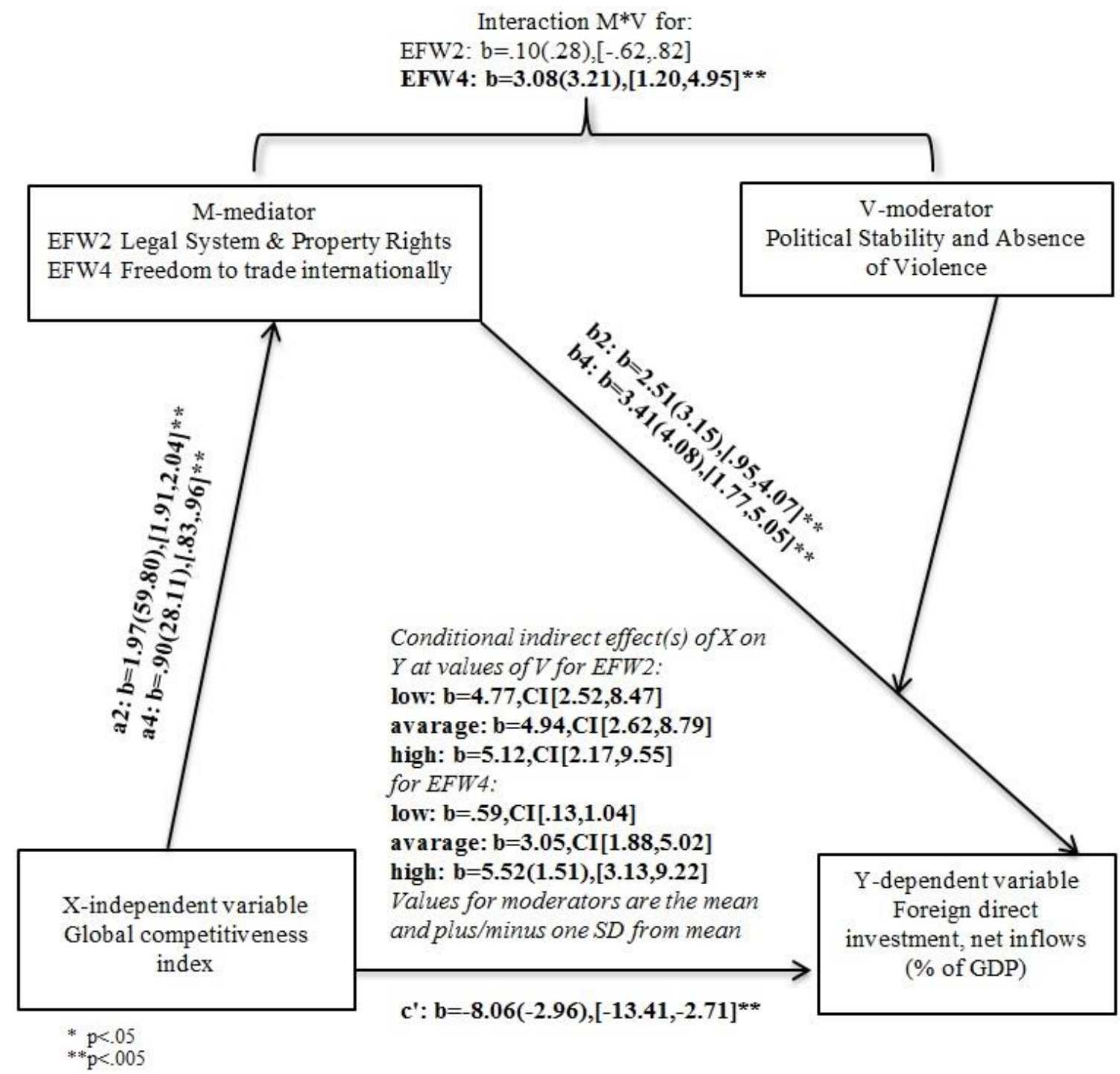

Figure 4. Moderated mediation

\section{Discussion}

From the previous studies given in the literature review, we have learned more about the impact of economic freedom on foreign direct investment. However, all these studies observed only a direct effect of economic freedom on FDI. Taking into account the findings provided by Quazi (2007), who separates the effects of economic freedom on FDI in China that are different compared with other countries from the research sample, we found a paradox suggesting that some countries with low level of economic freedom achieve a high degree of global competitiveness and stunning volume of inward FDI. Therefore, there was a clear need to determine whether economic freedom represents the real cause why a country's competitiveness contributes to an increase in inward FDI. Due to the confirmed relationship between global competitiveness and foreign direct investment supported by many scholars (Anastassopoulos, 2007; 
Curtis et al., 2013; Paul et al., 2014; Popovici \& Călin, 2015; Popovici \& Călin, 2012; Zlatković, 2016), it was highly justified to observe the indirect effects of economic freedom which have not been sufficiently explored by existing studies.

Bearing in mind that our parallel mediation analysis found statistically significant indirect effects for two mediators, namely Legal System \& Property Rights and Freedom to trade internationally, we are able to partially confirm our Hypothesis 1 limiting only to these two indicators of economic freedom. Other indicators within Fraser Institute's Economic Freedom of the World index do not represent a cause of positive effect of global competitiveness on inward FDI. From our findings we can conclude that the positive impact of competitiveness on inward FDI can be strengthened when we have a higher degree of Legal System \& Property Rights and Freedom to trade internationally. Thus, we oppose Wang, Xu, \& Zhu (2011) who claimed that the rule of law is not necessary for a country to attract FDI. Besides, our findings confirm previously expressed opinion on the importance of free trade for attracting foreign direct investment (Chankwon \& Yong Joon, 2013; Reed, Lira, Byung-Ki, \& Lee, 2016) (Chankwon \& Yong Joon, 2013; Li \& Maani, 2018; Reed et al., 2016). The indirect effect of Legal System \& Property Rights is much stronger and intense mediator compared to Freedom to trade internationally. Taking into account statistically significant direct effects of all individual indicators of economic freedom on inward FDI shown by Amponsem (2017), economic freedom indicators do not have the same effect when viewed as mediators within the proposed model of parallel mediation. Therefore, we can not fully agree with this scholar that all individual sub-components of economic freedom amplify FDI inflows.

Observing the influence of political stability, as a moderator between economic freedom and inward FDI, we can confirm our Hypothesis 2 for both selected indicators of economic freedom; Legal System \& Property Rights and Freedom to trade internationally. It is noticeable that under unstable political conditions there is no statistical significant effect between selected indicators of economic freedom and FDI.

Taking into account our findings, we cannot confirm the claim by Quazi \& Mahmud (2006) that the political instability significantly depresses the level of FDI is true at the global level. However, we cannot also support Kim (2010) that FDI inflows are large for politically unstable countries since we have not found a statistically significant moderating effect in case of low level of political stability.

By increasing the level of political stability Freedom to trade internationally, compared to Legal System \& Property Rights, achieves a much more intense effect on inward FDI. Our empirical findings support the claims expressed by Caetano \& Caleiro (2009) who believe that investments become very sensitive in relation to the degree of stability and security. If a particular country has established a proper legal system, adequate protection of property rights and secured free trade, then political instability in this country does not have high influence on inward FDI. On the other hand, increasing the level of political stability will provide a more intensive effect of selected indicators of economic freedom on inward FDI. With these findings we can explain what Brada et al. (2006) found that the Balkan countries under influence of low level of legal protection and high level of political instability receives much less FDI, comparing to other transition economies of Central Europe and the Baltics that succeeded with stabilization and reform in these areas.

The importance of trade openness, institutional reforms and competitiveness mentioned by Bassey \& Temitope (2015) can be confirmed as a very fundamental factor to attract foreign direct investment. From our second stage moderated mediation model, we found a statistically significant moderated mediation effect only for Freedom to trade internationally. This finding supports Hypothesis 3 for mediator Freedom to trade internationally while this hypothesis should be rejected for mediator Legal System \& Property Rights. Although both mediators, including Legal System \& Property Rights and Freedom to trade internationally, represent relevant causes for competitiveness in attracting foreign direct investment, only Freedom to trade internationally will provide statistically significant increases of conditional indirect effect of global competitiveness on foreign direct investment for politically more stable countries. This implies that increasing the level of Legal System \& Property Rights will not statistically increase the effect of competitiveness on FDI when the level of political stability increases. On the other side, by improving political stability, Freedom to trade internationally will significantly improve the positive effect of competitiveness on FDI. Due to the lack of significance of conditional indirect effect for most indicators of economic freedom, we cannot confirm the claim provided by Quazi \& Quddus (2018) that the FDI inflow is significantly depressed by the lack of economic freedom and increased political risk if we look on conditional effects between competitiveness and inward FDI.

To simplify our previous discussion, Legal System \& Property Rights, as confirmed cause in increasing positive effect of global competitiveness on inward FDI, is less sensitive to political risks and instability in the country compared to Freedom to trade internationally. Thus, it is a more stable indicator of economic freedom which contributes to the 
increase of FDI regardless of the level of political stability. Once a proper legal system and adequate protection of property rights are established, foreign investors will feel comfortable regardless of the political risks in the country.

\section{Conclusion}

Previous studies do not show whether the impact of competitiveness on foreign direct investment is achieved by the same intensity in countries with different levels of economic freedom and under different conditions of political stability. Therefore, application of the second stage moderated mediation model provides a more detailed insight into a rather complex problem. It enables understanding of an existing paradox according to which some countries with low levels of economic freedom achieve a high degree of global competitiveness and stunning volume of inward FDI.

Our empirical findings observed the mediation effects of all sub-components of Fraser's Institute Economic Freedom World (EFW) Index on the relationship between global competitiveness on inward foreign direct investment under different levels of political stability. We found that only two indicators of economic freedom, namely Legal System \& Property Rights and Freedom to trade internationally represent relevant causes for competitiveness in attracting foreign direct investments. Thus, strengthening economic freedom in these two dimensions provides an enhanced effect of existing competitiveness on FDI growth. We recognized that political stability has no influence on the indirect effects between competitiveness and inward FDI produced by Legal System \& Property Rights, as one of the dimensions of economic freedom. Therefore, to attract FDI in unstable political conditions is very useful to establish a proper legal system and adequate protection of property rights. In such a legal environment foreign investor will feel comfortable regardless of the political risks in the country. Freedom to trade internationally is a much more sensible mediator variable under the influence of political instability. For those countries that are politically stable, this dimension of economic freedom could be a very important cause to improve foreign direct investment.

Our empirical findings can serve as a basis for policy making and affirmation of reforms that can contribute to increasing the volume of inward foreign direct investment. Each country should work on building competitiveness factors, which will allow increasing its attractiveness towards foreign investors. Furthermore, it is necessary to analyse the political environment in order to perceive which dimensions of economic freedom can contribute in increasing the effects of competitiveness on FDI. Regardless of the level of political instability, each country needs to build its legal system to protect property and rights. In countries where political instability prevails, this form of economic freedom is particularly important in attracting FDI. In addition, it is necessary to allow free international trade especially in countries that are politically stable, as this will contribute to strengthening the effects of their own competitiveness on the level of foreign direct investment. In our study we used indicators of Fraser's Institute Economic Freedom World (EFW) Index to observe mediation effects of global competitiveness on inward FDI. In future empirical studies other indicators, such as Heritage Foundation Economic Freedom Index of the World, may be used which would complete the image of a very complex research problem.

This study indicated the necessity to analyse more factors in more complex model that can affect inflow of foreign direct investments which represents its major contribution. Particularly, the study was focused on economic freedom as mediating factor and political stability as moderating factor while analysing the effects of competitiveness on foreign direct investment. These factors can be considered as relatively static factors which do not have large oscillations over a shorter period, and this can be considered as one of the limitations of this study. Further research in this area may focus on the mediation effects of other factors, especially those that may have a sudden effect on the movement of foreign direct investment such as the financial crisis or a coronary virus pandemic.

\section{References}

Allen, F., Qian, J., \& Qian, M. (2005). Law, finance, and economic growth in China. Journal of Financial Economics, 77(1), 57-116. Retrieved from https://econpapers.repec.org/RePEc:eee:jfinec:v:77:y:2005:i:1:p:57-116

Almfraji, M. A., \& Almsafir, M. K. (2014). Foreign Direct Investment and Economic Growth Literature Review from 1994 to 2012. Procedia - Social and Behavioral Sciences, 129, $206-213$. https://doi.org/10.1016/j.sbspro.2014.03.668

Amponsem, F. (2017). the Effects of Economic Freedom on Inflows of Foreign.

Anastassopoulos, G. (2007). Countries' international competitiveness and FDI: an empirical analysis of selected EU member-countries and regions. Journal of Economics and Business, X(1), 35-52. Retrieved from http://www.u-picardie.fr/eastwest/fichiers/art58.pdf

Asiedu, E. (2002). On the Determinants of Foreign Direct Investment to Developing Countries: Is Africa Different?. World Development, 30(1), 107-119. https://doi.org/10.1016/S0305-750X(01)00100-0 
Baron, R. M., \& Kenny, D. A. (1986). The Moderator-Mediator Variable Distinction in Social Psychological Research. Conceptual, Strategic, and Statistical Considerations. Journal of Personality and Social Psychology, 51(6), 1173-1182. https://doi.org/10.1037/0022-3514.51.6.1173

Barro, R. J. (1991). Economic Growth in a Cross Section of Countries*. The Quarterly Journal of Economics, 106(2), 407-443. https://doi.org/10.2307/2937943

Bassey, S., \& Temitope, A. A. (2015). Government Regulation of Foreign Direct Investment Inflow and Sustainable Development in Sub-Saharan Africa, 284-290.

Bayar, Y., \& Aytemiz, L. (2015). Impact of economic freedom, political stability and economic growth in the USA on emerging Asian economies. Actual Problems of Economics (Vol. 168).

Bollen, K. A., \& Stine, R. (1990). Direct and Indirect Effects: Classical and Bootstrap Estimates of Variability. Sociological Methodology, 20, 115-140. https://doi.org/10.2307/271084

Brada, J., Kutan, A., \& Yigit, T. (2006). The Effects of Transition and Political Instability on Foreign Direct Investment Inflows. Economics of Transition, 14. https://doi.org/10.1111/j.1468-0351.2006.00272.x

Busse, M., \& Hefeker, C. (2007). Political risk, institutions and foreign direct investment. European Journal of Political Economy, 23(2), 397-415.

Caetano, J., \& Caleiro, A. (2009). Economic Freedom and Foreign Direct Investment: How Different are the MENA Countries from the EU. IBusiness, 1(2), 65-74. https://doi.org/10.4236/ib.2009.12010

Carmignani, F. (2003). Political Instability, Uncertainty and Economics. Journal of Economic Surveys, 17(1), 1-54. https://doi.org/10.1111/1467-6419.00187

Chankwon, B., \& Yong Joon, J. (2013). The Impact of Free Trade Agreements on Foreign Direct Investment: The Case of Korea. Journal of East Asian Economic Integration, 17(4), 417-445. https://doi.org/10.11644/KIEP.JEAI.2013.17.4.272

Corbo, V., \& Schmidt-Hebbel, K. (1991). Public policies and saving in developing countries. Journal of Development Economics, 36(1), 89-115. https://doi.org/10.1016/0304-3878(91)90006-H

Curtis, T., Rhoades, D. L., \& Griffin, T. (2013). Effects of Global Competitiveness, Human Development, and Corruption on Inward Foreign Direct Investment. Review of Business, 34(1), 67.

Edwards, J. R., \& Lambert, L. S. (2007). Methods for integrating moderation and mediation: A general analytical framework using moderated path analysis. Psychological Methods, 12(1), 1-22. https://doi.org/10.1037/1082-989X.12.1.1

Fernández-Arias, E., \& Hausmann, R. (2001). Is foreign direct investment a safer form of financing?. Emerging Markets Review, 2(1), 34-49. https://doi.org/10.1016/S1566-0141(00)00018-2

Ferreira, M., Carreira, H., Li, D., \& Serra, F. (2016). The Moderating Effect of Home Country Corruption on the Host Country's Ability to Attract FDI. Brazilian Business Review, 13(4), 94-117. https://doi.org/10.15728/bbr.2016.13.4.5

Fofana, M. F. (2014). The Influence of Measures of Economic Freedom on FDI: A Comparison of Western Europe and Sub-Saharan Africa. Global Economy Journal, 14. https://doi.org/10.1515/gej-2014-0023

Gwartney, J., Lawson, R., \& Hall, J. (2017). Economic Freedom of the World: 2017 Annual Report. Fraser Institute. Retrieved from https://www.fraserinstitute.org/studies/economic-freedom

Hayes, A. F. (2013). Introduction to mediation, moderation, and conditional process analysis: A regression-based approach. New York, NY, US: Guilford Press.

Hayes, A. F. (2015). An Index and Test of Linear Moderated Mediation. Multivariate Behavioral Research, 50(1), 1-22. https://doi.org/10.1080/00273171.2014.962683

Jaspersen, F. Z., Aylward, A. H., \& Knox, A. D. (2000). Risk and Private Investment: Africa Compared with Other Developing Areas BT - Investment and Risk in Africa. P. Collier, \& C. Pattillo (Eds.), pp. 71-95. London: Palgrave Macmillan UK. https://doi.org/10.1007/978-1-349-15068-7_3

Kaufmann, D., Kraay, A., \& Mastruzzi, M. (2010). The Worldwide Governance Indicators:Methodology and Analytical Issues. World Bank Policy Research Working Paper No. 5430, September 2010. SSRN. Retrieved from https://ssrn.com/abstract $=1682130$ 
Kim, H. (2010). Political stability and foreign direct investment. International Journal of Economics and Finance, 2(3), 59-72. Retrieved from http://ccsenet.org/journal/index.php/ijef/article/view/6822

Krugman, P. (2009). The Return of Depression Economics and the Crisis of 2008. New York: Norton \& Company.

Kurecic, P., \& Kokotovic, F. (2017). The Relevance of Political Stability on FDI: A VAR Analysis and ARDL Models for Selected Small, Developed, and Instability Threatened Economies. Economies, 5(3), 22. https://doi.org/10.3390/economies5030022

Li, Q., \& Maani, S. (2018). Detecting positive effects of the ASEAN-China free trade agreement on foreign direct investment. International Economics and Economic Policy, 15(1), 69-87. https://doi.org/10.1007/s10368-016-0366-y

Lockwood, C. M., \& Mackinnon, D. P. (1981). Bootstrapping the Standard Error of the Mediated Effect Chondra M. Lockwood, Arizona State University David P. MacKinnon, Arizona State University.

Loree, D. W., \& Guisinger, S. E. (1995). Policy and Non-Policy Determinants of U.S. Equity Foreign Direct Investment. Journal of International Business Studies, 26(2), 281-299. Retrieved from https://econpapers.repec.org/RePEc:pal:jintbs:v:26:y:1995:i:2:p:281-299

MacKinnon, D. P., Lockwood, C. M., \& Williams, J. (2004). Confidence Limits for the Indirect Effect: Distribution of the Product and Resampling Methods. Multivariate Behavioral Research, 39(1), 99. https://doi.org/10.1207/s15327906mbr3901_4

Mohamed, S. E., \& Sidiropoulos, M. (2010). Another Look At The Determinants Of Foreign Direct Investment In Mena Countries: An Empirical Investigation. Journal of Economic Development, 35(2), 75-95. Retrieved from https://econpapers.repec.org/RePEc:jed:journl:v:35:y:2010:i:2:p:75-95

Nageswaran, V. (2004). Foreign capital and open societies. Businessline.

Nazeer, A. M., \& Masih, M. (2017). Impact of political instability on foreign direct investment and Economic Growth: Evidence from Malaysia. Munch Personal RePEc Archive, (79418). https://doi.org/10.1227/01.NEU.0000349921.14519.2A

Paul, A., Popovici, O. C., \& Călin, C. A. (2014). The attractiveness of CEE countries for FDI. A public policy approach using the topsis method. Transylvanian Review of Administrative Sciences, (42), 156-180.

Pearson, D., Nyonna, D., \& Kim, K.-J. (2012). The Relationship Between Economic Freedom, State Growth And Foreign Direct Investment In US States. International Journal of Economics and Finance, 4(10), 140-147. https://doi.org/10.5539/ijef.v4n10p140

Popovici, O.-C., \& Cantemir Călin, A. (2015). The Effects of Enhancing Competitiveness on FDI Inflows in CEE Countries. European Journal of Interdisciplinary Studies, 7(1), 11.

Popovici, O., \& Călin, A. (2012). Competitiveness as Determinant of Foreign Direct Investments in Central And Eastern European Countries. Revista economică.

Preacher, K. J., \& Hayes, A. F. (2004). SPSS and SAS procedures for estimating indirect effects in simple mediation models. Behavior Research Methods, Instruments, \& Computers, 36(4), 717-731. https://doi.org/10.3758/BF03206553

Preacher, K. J., \& Hayes, A. F. (2008). Asymptotic and resampling strategies for assessing and comparing indirect effects in multiple mediator models. Behavior Research Methods, 40(3), 879-891. https://doi.org/10.3758/BRM.40.3.879

Preacher, K. J., Rucker, D. D., \& Hayes, A. F. (2007). Addressing Moderated Mediation Hypotheses: Theory, Methods, and Prescriptions. Multivariate Behavioral Research, 42(1), 185-227. https://doi.org/10.1080/00273170701341316

Quazi, R. (2007). Economic Freedom and Foreign Direct Investment in East Asia. Journal of the Asia Pacific Economy, 12(3), 329-344. https://doi.org/10.1080/13547860701405755

Quazi, R., \& Mahmud, M. (2006). Determinants of Foreign Direct Investment in South Asia.

Quazi, R., \& Quddus, M. (2018). Foreign Direct Investment and Investment Climate: Comparing Bangladesh with Selected Countries in South Asia.

Rani, K., \& Batool, Z. (2016). Impact of Political Instability and Foreign Direct Investment on Economic 
Development in Pakistan. Asian Economic and FinancialReview, 6(2), 83-89. https://doi.org/10.18488/journal.aefr/2016.6.2/102.2.83.89

Reed, R., Lira, C., Byung-Ki, L., \& Lee, J. (2016). Free Trade Agreements and Foreign Direct Investment: The Role of Endogeneity and Dynamics. Southern Economic Journal, 83. https://doi.org/10.1002/soej.12136

Schneider, F., \& Frey, B. S. (1985). Economic and political determinants of foreign direct investment. World Development, 13(2), 161-175. https://doi.org/10.1016/0305-750X(85)90002-6

Shrout, P. E., \& Bolger, N. (2002). Mediation in experimental and nonexperimental studies: New procedures and recommendations. Psychological Methods. https://doi.org/10.1037/1082-989X.7.4.422

Singh, H., \& Jun, K. W. (1995). Some new evidence on determinants of foreign direct investment in developing countries. Policy Research Working Paper Series. The World Bank. Retrieved from https://econpapers.repec.org/RePEc:wbk:wbrwps:1531

Sovbetov, Y., \& Moussa, M. (2017). Interaction of Economic Freedom and Foreign Direct Investment Globally: Special Cases from Neglected Regions. Journal of Economics and Financial Analysis, 1(1), https://doi.org/10.1991/Jefa.V1i1.A4

Schwab, K., Sala, I., \& Martin, X. (2017). Global Competitiveness Report 2017-2018. World Economic Forum. Retrieved from https://www.weforum.org/reports/the-global-competitiveness-report-2017-2018

Wang, X., Xu, L., \& Zhu, T. (2011, September). Foreign Direct Investment under Weak Rule of Law. Theory and Evidence from China, 31 .

World Bank Open Data. Retrieved from https://data.worldbank.org/

Zlatković, M. (2016). Does Enhancing of the Competitiveness Influence on Foreign Direct Investments in Western Balkan Countries, 8385, 164-173.

\section{Copyrights}

Copyright for this article is retained by the author(s), with first publication rights granted to the journal.

This is an open-access article distributed under the terms and conditions of the Creative Commons Attribution license (http://creativecommons.org/licenses/by/4.0/). 